\title{
Sustainable spatial development in higher education
}

Sustainable development is not only a great challenge for society as a whole, but also for higher education institutions, which have been rapidly including sustainable development in their educational process in the last two decades. Directly or indirectly, education for sustainable spatial development includes all aspects of sustainable development: environmental, economic, social and cultural. Space is a junction of various interests, which requires coordinating the entire process of spatial planning, taking into account the goal of sustainable spatial development. The existing values of space are insufficient for the rapid implementation of a sustainable spatial development paradigm. Suitable education is needed by both individuals and spatial planning professionals and at all levels of education. It is therefore necessary to transform some of the academic programs in the higher education curriculum by integrating teaching content and methods that include long-term knowledge and holistic thinking, taking into account the importance of interdisciplinary integration. This article reviews literature in sustainable development in higher education from 2002 to 2013. Topics discussed include students' and teachers' conceptions of sustainable development, the presence of sustainable development and sustainable spatial development in higher education and the reasons for the slow introduction of this material into the curriculum. Based on a literature analysis, the last section identifies important drivers that can contribute to a more rapid integration of a sustainable spatial development paradigm into higher education.

Keywords: sustainable development, sustainable spatial development, higher education, students, teachers, conception 


\section{Introduction}

An important tool for achieving sustainable development and spatial planning in accordance with a sustainable development paradigm is education for sustainable development. "Education for sustainable development ... promotes the development of the knowledge, understanding, values and actions required to create a sustainable world, which ensures environmental protection and conservation, promotes social equity and encourages economic sustainability" (Nevin, 2008: 50). Sustainable spatial development stems from the fact that space is limited in the physical sense and is often associated with the economical use of space in the Spatial Planning Act (Zakon o prostorskem načrtovanju, Ur. l. RS, no. 33/2007). It is assumed that the economical use of space in the present also allows the spatial development of future generations. To achieve this goal (i.e., economical use of space), taking into account the need for place and opportunities to satisfy those needs, the entire process of spatial planning should include the environmental, economic, social and cultural aspect of sustainability (see, e.g., Bizjak, 2012; Kušar, 2012; Hiremath et al., 2012; Zhang et al., 2012; Giliberti, 2013; Bratina Jurkovič, 2014; Hoxha et al., 2014, Yau et al., 2014). Space actually represents a junction of different interests, which requires coordinating the entire process of spatial planning, taking into account the goal of sustainable spatial development. This relatively new paradigm requires a different perception and understanding of space than in the past, by both individuals as well as spatial planning experts. The conduct of individuals and their spatial interference are affected mainly by "a system of values that a person establishes through education, parent education, the micro and macro social environment in which they live, communicate and are active" (Verovšek \& Juvančič, 2009: 44). Existing values of place are insufficient for the rapid implementation of a sustainable spatial development paradigm. Suitable education is needed by both individuals and spatial planning professionals at all levels of education. The consequences of not integrating sustainable spatial development into education can result in prolonged inertia of the existing system of values in terms of space and permanent, ongoing consequences for future generations. The formal education system has an important role in education for values of space and has a significant impact on increasing awareness of sustainable spatially oriented topics and appropriate transfer of spatial contents, "which are able to convey complex messages in a clear, understandable and accessible form to the target audience" (Verovšek et al., 2013: 66). Simon Kušar (2008: 41) states that "the ultimate goal of education in spatially oriented topics is to make people aware of the complexity of spatial problems, the values of space, to know how to protect and to realise their own possibilities for active participation, which may contribute to the conservation values of space or prevent it from being devalued". Similarly, according to Špela Verovšek and Matevž Juvančič (2009: 44), integrating sustainable spatial development into the curriculum helps individual know how to "[p]roperly install built structures in the previously more or less shaped space ... to understand the design, material characteristics of space and to understand the coherence of the effects and consequences, that individual actions are likely to cause" [sic]. All of the above applies even more so because future professionals planning spatial development accept and implement decisions regarding interventions in space. They have to be familiar with both potential problems and disputes in accordance with the sustainable development paradigm. For spatial planning experts, in addition to education at primary and secondary level, education at a higher level also plays an important role.

This article analyses the state of play in sustainable development in higher education, based on an analysis of research findings, and identifies key factors that may contribute to more rapid incorporation of a sustainable spatial development paradigm into higher education.

With the help of published reviewed articles, we seek to answer the following questions:

- How are sustainable development and sustainable spatial development represented in higher education?

- How do students and teachers conceptualise sustainable development in higher education?

- Which measures would encourage introduction of a sustainable spatial development paradigm into the curriculum and consequentially also its implementation?

The following objectives are based on the answers to these questions:

- Defining the role of education for sustainable development in higher education.

- Developing a platform for integrating adaptation methods and dealing with sustainable spatial development in higher education.

\section{Theoretical frameworks}

Since the publication of Our Common Future (World Commission on Environment and Development, 1987) and Agenda 21 (United Nations Conference on Environment and Development, 1992), the concept of sustainable development has been part of people's everyday lives and has been involved in many activities. Although the latest standard Slovenian dictionary (Sln. Slovar slovenskega knjižnega jezika; Gliha Komac, et al., 2014), does not indicates this, it is worth mentioning that recent literature has sometimes replaced the concept of sustainability with the concept of sustainable develop- 
ment (see Internet 1). The concept of "sustainability" in the standard Slovenian dictionary (Gliha Komac et al., 2014: 764) is defined relatively narrowly as "a characteristic of something depending on how long it can exist, is useful: to increase the sustainability of a car; determine the sustainability of milk; a permanent feature: to defend the sustainability of education / to recommend colours for durability - persistency." Because the concept of "sustainability" is expected be defined in standard Slovenian as "development direction" only in the future, this paper uses the concept of sustainable development, which is currently used by large global organisations. As an example, just a few of them are listed below. The European Commission uses the concept of sustainable development in its new document for the seventh Environment Action Programme: Living Well, within the Limits of our Planet (European Commission, 2014). The United Nations Division for Sustainable Development, Department of Economic and Social Affairs uses the term sustainable development in its most recent document, The Road to Dignity by 2030: Ending Poverty, Transforming All Lives and Protecting the Planet (United Nations, 2014). The University of Maribor uses the term sustainable development in the new Strategy for the Development of the University of Maribor 2013-2020 (Sln. Strategije razvoja Univerze v Mariboru 2013-2020; University of Maribor, 2013). Likewise the dictionary of newer standard Slovene vocabulary (Sln. Slovar novejšega besedja slovenskega jezika; Bizjak Končar et al., 2013: 364) states: "sustainable development ... sustainable development is development that meets the needs of the present generation without compromising the ability of future generations to meet their own needs."

In the past, higher educational institutions played an important role in shaping society through education decisionmakers, leaders, entrepreneurs and academics (Cortese, 2003; Elton, 2003; Lozano, 2006, 2011, 2012) and serving the public good (Mulder, 2010; Waas et al., 2010). In many ways, these institutions are still extremely traditional (Elton, 2003) because they contribute to or even promote unsustainable development (Sterling \& Scott, 2008; Wals, 2008) and remain resistant to change. The result is the preservation of the Cartesian paradigm (Nonaka \& Takeuchi, 2001; Lovelock, 2007), which was beneficial to society in many cases, but also contributed to the focus on conquering nature and industrialisation of the planet, which produced unbalanced, over-specialised and mono-disciplinary graduates (Costanza, 1991; Orr, 1992; Wemmenhove \& de Groot, 2001; Lozano, 2006; Cortese, 2003). Sustainable development is a relatively new paradigm, which is slowly being introduced in most higher education institutions. In Thomas Kuhn's (1970) view of paradigmatic changes in science, as a new paradigm appears, the older paradigm gradually disappears, which is mainly due to the new paradigm's acceptance by the new generation, its partial acceptance by the older generation, or the older generation's retirement or death. However, in part of the system individuals cling to the old paradigm, such as some educational departments, faculties or universities. The introduction of innovations such as sustainable development in higher education is even more difficult when the adopter is an organisation rather than individual (Rogers, 1995), especially if the innovation is an abstract idea (Rogers, 1995; Van de Ven et al., 1999; Lozano, 2006). For sustainable development to become an integral part of higher education and the part of wider system, it must be implemented in practice long enough and through the participation of a large number of employees within the system for it to attain widespread implementation (Lozano, 2006). In this process, higher education institutions should realise that they are not isolated islands in society, and that they must be open to knowledge acquired outside their walls (from other higher education institutions, companies, government or civil society; Richter \& Schumacher, 2011). This openness of higher education institutions can contribute to the creation, promotion and implementation of new, more sustainable paradigms in all its activities. Transforming the policy of European higher education in the classification system of university ranking could also contribute to a fairer and more equal society. Currently, the Shanghai ranking system and THE-QS are the most important ranking systems in higher education; however, they are both strongly focused solely on quantitative performance research (Erkkila, 2014) and are subject to numerous criticisms (Kauppi \& Erkkila, 2011). The European Commission has therefore encouraged the development of a new university evaluation system, which represents a deviation from the ranking of universities based solely on the evaluation of research work. The latest "[1]isting U-Multirank classifies universities according to set of 30 indicators in five areas: reputation for research, quality of teaching and learning, international orientation, success in knowledge transfer and economic growth" [sic] (Commission for Assessing the Quality of the University, 2014: 3). This classification of higher education institutions is an important innovation in this field and opens up new possibilities for introducing and considering a sustainable development paradigm in the university ranking system.

"Higher education has a direct and indirect impact on the local, regional, national and global environment and also on graduates and their decisions in the future" (Lukman, 2009: 9). Education for sustainable development, mainly in higher education, is a major challenge because of the great responsibility for the formulation and expression of ethical and technological knowledge, which, according to Tarah Wright (2006), is necessary to ensure the quality of life for present and future generations. In Slovenia, in the last decade, the number of studies in education for sustainable development, especially in higher education, has been increasing. The United Nations Economic 
Commission for Europe adopted the Strategy for Education for Sustainable Development in 2005 in Vilnius. Based on the cooperation of the countries involved, including Slovenia, in 2006 the joint report Environment for Europe was created, in which Slovenia identified the following deficiencies that must be eliminated as soon as possible (Ministry of Education and Sport, ${ }^{[1]}$ 2007a) to provide a basis for good-practice examples and a range of teaching materials for education for sustainable development, to create educational programs and a range of teaching materials for education for sustainable development for primary and secondary level, to create greater coherence between projects and activities in education for sustainable development, to create a need for a broader, holistic approach to education for sustainable development, to improve practice with environmental aspects of sustainable development, to create a need for dealing more with informal and informal education, to create the necessary national quality indicators, to create a need for evaluating programs and projects currently underway (Eco School, Healthy Schools, etc.) and to increase the amount of professional material on education for sustainable development. The joint Report of the Economic Commission for Europe (see Economic Commission for Europe, 2007) also mentioned that Slovenia has a decentralised educational and political system that allows institutions at the local level to develop their own interpretations of education for sustainable development. Based on proposals from the Working Group on Sustainable Development of Education, which included representatives of several ministries, departments, non-governmental organisations and civil society, in 2007 the Ministry of Education and Sport adopted its Guidelines for Education for Sustainable Development from Preschool to Pre-University Education (Sln. Smernice vzgoje in izobraževanja za trajnostni razvoj od predšlske vzgoje do douniverzitetnega izobraževanja; see Ministry of Education and Sport, 2007b). University education was excluded from these guidelines. Their purpose is "to emphasise the importance of education for sustainable development and demonstrate the possibilities for achieving sustainable development in formal, non-formal and informal learning" (Ministry of Education and Sport, 2007b: 2). In integrating the sustainable development paradigm into the curriculum, Slovenia relies on many international documents in sustainable development education and on the guidelines adopted in 2007, but the integration of sustainable development into education is still only something on paper, particularly in higher education. Similarly, a spatial planning study by the Economic Commission for Europe (2008) states that the policy of sustainable development is rarely given high priority, especially in spatial development in relation to spatial development programs, plans and practices. Anton Mlinar (2010a: 120) states that "the Slovenian education system devotes commensurate attention to sustainable development at the primary level ..., at the secondary level awareness is declining rapidly", which Kokot Kranjc et al. (2011) also agree with, stating that "[a]t the university level sustainability as paradigm of education is almost completely absent" [sic], as indicated also by results of the survey Slovenian Universities on the Perception of Sustainable Development, which was carried out as part of the project Ethics in Education for Sustainable Development (see Mlinar, 2010b). "Although the Slovenian universities are gradually introducing teaching programs on various aspects of sustainability, mainly the environmental aspect with some emphasis on "clean technology", the idea of sustainable development as a modified opinion is not yet integrated into higher education" (Mlinar, 2010a: 127). At the University of Ljubljana, the Faculty of Architecture and the Faculty of Civil and Geodetic Engineering, urban architectural workshops and seminars in spatial planning, aimed at developing concepts for high-quality regulation of the built and natural environment, have already been carried out for a decade, taking into account the interdisciplinary field of spatial planning and thus the objective of sustainable spatial development (Koželj, 2012; Zavodnik Lamovšek \& Foški, 2012, cited in Gabrijelčič \& Fikfak, 2012). The learning outcomes and the competences attained by these students have not been analysed yet; nevertheless, we may conclude that these activities have only an individual basis and are not part of the overall education of future professionals in spatial planning in accordance with a sustainable development paradigm. The University of Maribor is also active in sustainable development. A 2012 strategy document states that University of Maribor "wishes to use a positive example to create an innovative environment and efficient organisation, which will contribute to the quality, balanced, sustainable and socially responsible development of the university, city and country through the development, creation and transmission of key knowledge" (Rebolj et al., 2012: 1).

\section{Methods}

Articles were selected from the electronic databases Web of Science, ProQuest, Scopus and Google Scholar. The articles were collected from April 2012 to December 2013. The total numbers of articles gathered was initially four hundred. The following keywords and phrases were used: sustainable development, sustainable spatial development, university education, higher education, university, faculty, education for sustainable development, sustainability, teaching methods, curriculum, teachers, students, conceptions, and attitudes. Based on reading the full articles, we gathered articles that deal with sustainable development and sustainable spatial development mainly in higher education. For a more detailed analysis, we initially used seventy-one articles; later we selected thirty-two of these. The criterion for the final selection of articles was teaching and learning for sustainable development. The findings from analysing the thirty-two articles are presented in detail in Table 1. 
Table 1: Sustainable development and sustainable spatial development in higher education.

\begin{tabular}{|c|c|c|c|c|c|}
\hline No. & Author, year, journal & Article & Topic & $\begin{array}{l}\text { Methods and } \\
\text { techniques }\end{array}$ & Findings \\
\hline & \multicolumn{5}{|c|}{ Sustainable development in higher education in general } \\
\hline 1. & $\begin{array}{l}\text { Azapagic et al., } 2005 \\
\text { European Journal of Engi- } \\
\text { neering Education }\end{array}$ & $\begin{array}{l}\text { How much do engineering } \\
\text { students know about sustain- } \\
\text { able development? }\end{array}$ & $\begin{array}{l}\text { Conceptions of } \\
\text { sustainable develop- } \\
\text { ment, students }\end{array}$ & Questionnaire & $\begin{array}{l}\text { Lack of knowledge about sus- } \\
\text { tainable development, integrat- } \\
\text { ing theory and practice }\end{array}$ \\
\hline 2. & $\begin{array}{l}\text { Bjorneloo et al., } 2007 \\
\text { UNESCO }\end{array}$ & $\begin{array}{l}\text { Drivers and barriers for } \\
\text { implementing learning for } \\
\text { sustainable development in } \\
\text { pre-school through upper } \\
\text { secondary and teacher edu- } \\
\text { cation }\end{array}$ & $\begin{array}{l}\text { Education for sustain- } \\
\text { able development, } \\
\text { students, teachers }\end{array}$ & Workshop & $\begin{array}{l}\text { Confusion regarding the con- } \\
\text { cept of sustainable develop- } \\
\text { ment, promoting sustainable } \\
\text { behaviour }\end{array}$ \\
\hline 3. & $\begin{array}{l}\text { Carew \& Mitchell, } 2002 \\
\text { European Journal of Engi- } \\
\text { neering Education }\end{array}$ & $\begin{array}{l}\text { Characterising undergraduate } \\
\text { engineering students' under- } \\
\text { standing of sustainability }\end{array}$ & $\begin{array}{l}\text { Conception of sus- } \\
\text { tainable develop- } \\
\text { ment, students }\end{array}$ & $\begin{array}{l}\text { Questionnaire, } \\
\text { criterion: struc- } \\
\text { ture of observed } \\
\text { learning out- } \\
\text { comes }\end{array}$ & $\begin{array}{l}\text { Facilitating the transfer of } \\
\text { knowledge about sustainable } \\
\text { development, critical, creative } \\
\text { thinking }\end{array}$ \\
\hline
\end{tabular}

Cheal Ryu \& Brody, 2006 Examining the impacts of a

4. International Journal of graduate course on sustainSustainability in Higher able development using Education

Cotton et al., 2007

5. Environmental Education Research

Department of Environ- future. A national environment and Heritage, 2005 mental education statement for Australian school [sic]

Effeney \& Davis, 2013

7. Australian Journal of Teacher Education

Eyuboglu et al., 2010

8. International Review of Business Research Papers

Fadeeva \& Mochizuki,

9. 2010

Sustainable Science

Education for sustainability:

A case study of pre-service primary teachers' knowledge and efficacy

Education for sustain- Questionable development, students naire (ecological footprint)

Education increases the understanding of sustainable development

Sustainability development, higher education and pedagogy: A study of lecturers' beliefs and attitudes

Conception of sustainable development, teachers, curriculum

Education for sustainable development, Statement curriculum

Questionnaire

A wide range of understanding about sustainable development

The relationship between knowledge Case study, ques-

and efficiency, teach- tionnaire ers Attitudes of university students towards economic and sustainable development in Istanbul

Conception of sustainable development, students Higher education for today and tomorrow: University appraisal for diversity, innovation and change towards sustainable development

Ferreira et al., 2007

10. Australian Journal of Environmental Education

Planning for success: Factors Challenges, changes and opportunities in sustainable development

ducation for sustain- initiatives on influencing change in teacher able development, education of education teachers

Ferreira et al., $2009 \quad$ Mainstreaming sustainability Education for sustain-

11. Australian Journal of into pre-service teacher education in Australia

able development, students Environmental Education

Ferrer-Balas et al., 2010

Going beyond the rhetoric: System-wide changes in universities for sustainable societies
Values, point of view motives, curriculum, social interaction, teachers, teaching methods
Questionnaire

Project

Project about sustainable development

Review article, sustainable de-

Factors in implementing a sustainable development project velopment

Effectiveness and factors in the implementation a sustainable development project

Statement about sustainable development

Teachers' competences for education for sustainable development

Lack of knowledge about sustainable development, media and sustainable development

Review article Participatory approach duction 


\begin{tabular}{|c|c|c|c|c|c|}
\hline No. & Author, year, journal & Article & Topic & $\begin{array}{l}\text { Methods and } \\
\text { techniques }\end{array}$ & Findings \\
\hline & \multicolumn{5}{|c|}{ Sustainable development in higher education in general } \\
\hline 13. & $\begin{array}{l}\text { Kagawa, } 2007 \\
\text { International Journal of } \\
\text { Sustainability in Higher } \\
\text { Education }\end{array}$ & $\begin{array}{l}\text { Dissonance in students' per- } \\
\text { ceptions of sustainable de- } \\
\text { velopment and sustainability: } \\
\text { Implications for curriculum } \\
\text { change }\end{array}$ & $\begin{array}{l}\text { Conception of sus- } \\
\text { tainable develop- } \\
\text { ment, students }\end{array}$ & Questionnaire & $\begin{array}{l}\text { Lack of knowledge of about } \\
\text { sustainable development }\end{array}$ \\
\hline 14. & Kolenc Kolnik, 2009 & $\begin{array}{l}\text { Geographical education is } \\
\text { an important part of educa- } \\
\text { tion for sustainable devel- } \\
\text { opment (SIn. Geografsko } \\
\text { izobraževanje je pomemben } \\
\text { del izobraževanja za trajnost- } \\
\text { ni razvoj) }\end{array}$ & $\begin{array}{l}\text { Education for sustain- } \\
\text { able development, } \\
\text { curriculum, teaching, } \\
\text { methods }\end{array}$ & Review article & Experiential method \\
\hline 15. & $\begin{array}{l}\text { Lozano, } 2006 \\
\text { Journal of Cleaner Pro- } \\
\text { duction }\end{array}$ & $\begin{array}{l}\text { Incorporation and institution- } \\
\text { alisation of sustainable de- } \\
\text { velopment into universities: } \\
\text { Breaking through barriers to } \\
\text { change }\end{array}$ & $\begin{array}{l}\text { Reasons for the slow } \\
\text { introduction of sus- } \\
\text { tainable development } \\
\text { into the curriculum }\end{array}$ & Review article & $\begin{array}{l}\text { Gradual introduction of sustain- } \\
\text { able development, focus on } \\
\text { all three aspects of sustainable } \\
\text { development }\end{array}$ \\
\hline 16. & $\begin{array}{l}\text { Lozano, } 2010 \\
\text { Journal of Cleaner Pro- } \\
\text { duction }\end{array}$ & $\begin{array}{l}\text { Diffusion of sustainable de- } \\
\text { velopment in universities' cur- } \\
\text { ricula: An empirical example } \\
\text { from Cardiff University }\end{array}$ & Curriculum & $\begin{array}{l}\text { Quantitative } \\
\text { analysis }\end{array}$ & $\begin{array}{l}\text { Balanced, holistic, synergistic } \\
\text { and cross-disciplinary thinking }\end{array}$ \\
\hline 17. & $\begin{array}{l}\text { Lukman, } 2009 \\
\text { University of Maribor }\end{array}$ & $\begin{array}{l}\text { Sustainability in higher edu- } \\
\text { cation: An efficient and envi- } \\
\text { ronmentally responsible uni- } \\
\text { versity (SIn. Trajnostni razvoj v } \\
\text { visokošolskem izobraževanju: } \\
\text { Učinkovita in okoljsko odgo- } \\
\text { vorna univerza) }\end{array}$ & $\begin{array}{l}\text { Representation of } \\
\text { sustainable develop- } \\
\text { ment topics in } \\
\text { curricula }\end{array}$ & $\begin{array}{l}\text { Review of the } \\
\text { curriculum study } \\
\text { of the classifica- } \\
\text { tion system for } \\
\text { sustainable terms } \\
\text { and definitions }\end{array}$ & $\begin{array}{l}\text { Low content integration of } \\
\text { sustainable development in } \\
\text { curriculum }\end{array}$ \\
\hline 18. & $\begin{array}{l}\text { Mlinar, 2010a } \\
\text { Annales }\end{array}$ & $\begin{array}{l}\text { Paradigm of sustainability } \\
\text { and a university. The sur- } \\
\text { vey in Slovenian universi- } \\
\text { ties with special reference } \\
\text { to University of Primorska } \\
\text { [sic] (Sln. Paradigma trajnosti } \\
\text { in izobraževanje. Raziskava na } \\
\text { slovenskih univerzah s poseb- } \\
\text { nim ozirom na Univerzo na } \\
\text { Primorskem) }\end{array}$ & $\begin{array}{l}\text { Conception of } \\
\text { sustainable devel- } \\
\text { opment, students, } \\
\text { teachers, curriculum }\end{array}$ & Questionnaire & $\begin{array}{l}\text { Strengthening ethical con- } \\
\text { science }\end{array}$ \\
\hline 19. & $\begin{array}{l}\text { Reid \& Petocz, } 2006 \\
\text { Higher Education }\end{array}$ & $\begin{array}{l}\text { University lecturers' under- } \\
\text { standing of sustainability }\end{array}$ & $\begin{array}{l}\text { Conception of } \\
\text { sustainable devel- } \\
\text { opment, teachers, } \\
\text { curriculum, teaching } \\
\text { methods }\end{array}$ & Research project & $\begin{array}{l}\text { Change in thinking and creative } \\
\text { thinking, obstacles in education } \\
\text { sustainable development }\end{array}$ \\
\hline 20. & $\begin{array}{l}\text { Reid et al., } 2009 \\
\text { Sustainability }\end{array}$ & $\begin{array}{l}\text { Business students' concep- } \\
\text { tions of sustainability }\end{array}$ & $\begin{array}{l}\text { Conception of } \\
\text { sustainable devel- } \\
\text { opment, students, } \\
\text { teachers }\end{array}$ & $\begin{array}{l}\text { Interview, project } \\
\text { work }\end{array}$ & $\begin{array}{l}\text { Lack of understanding of sus- } \\
\text { tainable development, lack of } \\
\text { competence and confidence } \\
\text { in teaching about sustainable } \\
\text { development }\end{array}$ \\
\hline 21. & $\begin{array}{l}\text { Robinson, } 2008 \\
\text { Futures }\end{array}$ & $\begin{array}{l}\text { Being undisciplined: Trans- } \\
\text { gressions and intersections in } \\
\text { academia and beyond }\end{array}$ & $\begin{array}{l}\text { Teaching methods, } \\
\text { interdisciplinary } \\
\text { teaching, problem- } \\
\text { based learning, inte- } \\
\text { gration }\end{array}$ & Literature review & $\begin{array}{l}\text { Interdisciplinary, problem solv- } \\
\text { ing, integration, reflectivity and } \\
\text { cooperation }\end{array}$ \\
\hline
\end{tabular}




\begin{tabular}{|c|c|c|c|c|c|}
\hline No. & Author, year, journal & Article & Topic & $\begin{array}{l}\text { Methods and } \\
\text { techniques }\end{array}$ & Findings \\
\hline & \multicolumn{5}{|c|}{ Sustainable development in higher education in general } \\
\hline 22. & $\begin{array}{l}\text { Sarewitz et al., } 2012 \\
\text { New Solutions }\end{array}$ & $\begin{array}{l}\text { The sustainability solution } \\
\text { agenda }\end{array}$ & $\begin{array}{l}\text { Project agenda for } \\
\text { sustainable solutions }\end{array}$ & Project & $\begin{array}{l}\text { Sustainable development } \\
\text { project }\end{array}$ \\
\hline 23. & $\begin{array}{l}\text { Stir, } 2006 \\
\text { Journal of Cleaner Pro- } \\
\text { duction }\end{array}$ & $\begin{array}{l}\text { Restructuring teacher educa- } \\
\text { tion for sustainability: Stu- } \\
\text { dent involvement through a } \\
\text { strength model }\end{array}$ & $\begin{array}{l}\text { Conception of sus- } \\
\text { tainable develop- } \\
\text { ment, teachers }\end{array}$ & Questionnaire & $\begin{array}{l}\text { Lack of competence in teaching } \\
\text { about sustainable development }\end{array}$ \\
\hline 24. & $\begin{array}{l}\text { Summers et al., } 2004 \\
\text { Educational Research }\end{array}$ & $\begin{array}{l}\text { Student teachers conceptions } \\
\text { of sustainable development: } \\
\text { The starting-points of geog- } \\
\text { raphers }\end{array}$ & $\begin{array}{l}\text { Conception of sus- } \\
\text { tainable develop- } \\
\text { ment, students, cur- } \\
\text { riculum }\end{array}$ & Questionnaire & $\begin{array}{l}\text { Lack of students' knowledge } \\
\text { about sustainable development }\end{array}$ \\
\hline 25. & $\begin{array}{l}\text { Vovk Korže, } 2012 \\
\text { Geography }\end{array}$ & $\begin{array}{l}\text { Challenging assumptions: The } \\
\text { ecoremediation educational } \\
\text { polygon: a classroom in na- } \\
\text { ture [sic] }\end{array}$ & $\begin{array}{l}\text { Ecoremediation as a } \\
\text { sustainable approach } \\
\text { to environmental } \\
\text { management }\end{array}$ & $\begin{array}{l}\text { Project work with } \\
\text { an activity area }\end{array}$ & $\begin{array}{l}\text { The opportunity to develop an } \\
\text { integrated and holistic under- } \\
\text { standing of the natural environ- } \\
\text { ment }\end{array}$ \\
\hline
\end{tabular}

Sustainable spatial development in primary and secondary education

The importance of teachers'

Fridl et al., 2009

26. Acta geographica Slovenica perception of space in education (SIn. Pomen učiteljevega zaznavanja prostora $v$ izobraževalnem procesu)

The perception of Brainstorming, space through spatial fieldwork, role perception teachers play
Diverse and interesting methods, good motivation for students, primary and secondary school
Space values as integral part

Resnik Planinc, 2006

Simoneti, 2006

Urbani izziv

of education [sic] (SIn. Vredizobraževanja)

Education for cooperation:

Spatial planning needs to be taught! (SIn. Izobraževanje za
Geodetski vestnik

note prostora kot integralni del sodelovanje: urejanje prostora mora $v$ šolo!)

Education on the built environment for sustainable

Zupančič et al., 2009

29. Ciljni raziskovalni program
The importance of

education,

part of the R.A.V.E. Research space project, teach-

ers

\section{Education about spa-}

tial planning, R.A.V.E. Review article Corporation

space project

development in Slovenia: Fi- Sustainable spatial

nal report (SIn. Izobraževanje development, curo grajenem okolju za tra- riculum

jnostni razvoj Slovenije: končno

poročilo)
Insufficient dealing with content in sustainable spatial development

Sustainable spatial development in higher education
The "sustainable develop-

Dimitrova, 2014

ment" concept in urban

30. Journal of Cleaner Proplanning education: Lessons duction learned on a Bulgarian path

Establish and development of Project question- cultural identity, connection of naire measures to achieve sustainable development
31. Hamza \& Horne, 2007

Building and Environment

An operational model for teaching low energy archi- Curriculum tecture

Overview of an innovative

32. Yao et al., 2009 Renewable Energy
EU-China collaboration in education and research in sustainable built environment
The gradual integration of sustainable development and cooperation
Education and dissemination of information

Curriculum
Education and dis-
semination of infor-
mation

Module:

Information and

communications Integration

technology

Questionnaire

Internet exchange network of information on sustainable development 
The table is divided into two parts: the first part shows articles in education for sustainable development in general, and the second part shows articles in education for sustainable spatial development, separately for primary and secondary education and for higher education. We assume that the conclusions of the articles in the first part are important for creating starting points for integrating and considering sustainable spatial development in higher education. The same is true for the conclusions of the articles at the level of primary and secondary education. Knowledge of the conclusions at this level can also contribute to more rapid integration of material discussed in higher education curricula. Based on a qualitative analysis of the articles, Table 1 presents the author, year, journal, article title, topics discussed, methods and techniques, and findings. The main themes were identified based on content analysis and are presented in the paragraph about the findings inside the three main themes: sustainable development in higher education, students' conceptions of sustainable development and teachers' conceptions of sustainable development, and two sub-themes: sustainable spatial development in primary and secondary education as the starting point for integrating the sustainable spatial development paradigm into higher education, and sustainable spatial development in higher education. This is followed by a section in which we discuss the reasons for the lack of integration of sustainable development and measures to promote the integration of sustainable spatial development in higher education.

\section{Findings of the review articles and discussion}

\subsection{Sustainable development in higher education}

In the last decade, a number of higher education institutions have begun to take responsibility for a sustainable future and for introducing the topics of sustainable development in the curriculum, while exploring, operating, assessing and reporting on achievements in sustainable development (Ferrer-Balas et al., 2010; Lozano, 2010). The results of one of the largest studies, which analysed the 5,800 teaching subjects at nineteen schools at Cardiff University, have shown that successful integration of the elements of sustainable development in the curriculum requires transformation from specialised and narrowly focused thinking to more balanced, holistic, synergistic and cross-disciplinary thinking (Lozano, 2010) and participation of all concerned (Lozano, 2006). "A common feature and cross-curricular tendency of all educational fields is the emphasis on values and training in practical activities and rational (democratic) decision-making, which should be based on high-quality, flexible, well-understood and integrated knowledge and often exceeds the current prevailing substantive learning correlations" (Kolenc Kolnik, 2009: 452). Similarly, Mlinar (2010a: 120) also believes that "the future of higher education is based on sustainability, but this requires a conscious participation in the change, which includes the entire system of science and a deepening understanding of ethical awareness." To achieve effective education in sustainable development, it is also necessary to understand the broad spectrum of cross-disciplinary concepts and themes (Department of Environment and Heritage, 2005; Ferreira et al., 2009), such as a participatory approach to the development and dissemination of new sustainability standards (Ferrer-Balas et al., 2010), integration of principles of sustainable development into existing educational programs (Hamza \& Horne, 2007), experiential methods for acquiring knowledge and values based on fieldwork (Kolenc Kolnik, 2009; Vovk Korže, 2012), interdisciplinary, problem-solving, integration, reflectivity and cooperation (Robinson, 2008), establishing and developing cultural identity and integration of measures to achieve sustainable development (Zupančič Strojan et al., 2009). Daniel Sarewitz et al. (2012) state that measures for success do not lie in newly acquired knowledge, but in solutions achieved in the real world. The study involving graduate students in architecture, urban planning and land development provides insight into the effectiveness of teaching sustainable spatial development in higher education. The results indicate that education for sustainable development can significantly enhance the sustainable performance of students in the future (Cheal Ryu \& Brody, 2006). The research results are based on calculations from a questionnaire about ecological footprints. However, some studies (see Bjorneloo \& Nyberg, 2007, or Ferreira et al., 2007) indicate that the majority of training courses aimed at future teachers contain very few topics in sustainable development or, indeed, no topics relating to this issue at all. Research by Rebekah Lukman (2009: 123), which is related to the diversity and frequency of sustainability-oriented subjects in the curriculum, showed that "only a small proportion of programmes include subjects from the group of new trends and sustainable development." According to Inger Bjorneloo and Eva Nyberg (2007), what people do and how they act is important, and not how they name sustainable development. They also emphasise the need to promote new patterns of behaviour. One method is a publication on sustainable development, which provides a legal basis for developing education for sustainable development, or a statement containing the principles of good practice for training and principles of sustainable development, balance, values and attitudes (Department of Environment and Heritage, 2005) or, for example, a project that is not only a basis for common creativity and dissemination of information and good-practice examples, but mutual cooperation in the experiment, coping with difficulties and building academic partnership relations (Fadeeva \& Mochizuki, 2010). Individual initiatives, project work and programmes (which are affected many 
factors, such as initiative, and the personality and ability of leaders) seek to introduce a range of new teaching strategies to provide opportunities for teachers and other interested parties to consider how they can use these learning strategies in their teaching (Ferreira et al., 2007, 2009).

Slovenias four universities have integrated the basic principles of sustainable development into their curriculum (Mlinar, 2010a) and are taking responsibility for a sustainable future. The University of Maribor's priorities for a sustainable and socially responsible university (Sln. Prioritete Sveta za trajnostno in družbeno odgovorno univerzo) for 2013 places great emphasis on content in sustainability, especially in society and education, the economy and the environment. The objectives in sustainable development and education at the University of Maribor are as follows: "to encourage and incorporate sustainable development and social responsibility in the curriculum, to promote informal education of students and staff, to promote the involvement of local communities in education for sustainable development and to corporate social responsibility, ... to promote lifelong learning" (University of Maribor, 2013: 1). Through a variety of activities, such as integration of topics about sustainability and social responsibility into all courses and the introduction of a compulsory course, these objectives are intended to achieve the basics of sustainable development and social responsibility in all faculties and modules for the bachelor's, master's and doctoral level, setting up a centre for education on sustainable development, presentation of the best sustainable solutions (once a year), contests for innovative solutions for achieving sustainable development, and so on. As part of its bachelor's and master's programmes, the University of Maribor and its member faculties conduct courses and modules in sustainable development. Activities at the University of Ljubljana in sustainable development also focus on three areas: society, the economy and the environment; for example, the Sustainable Development Strategy (Sln. Strategija trajnostnega razvoja) of the Faculty of Economics in Ljubljana emphasises that knowledge, innovation and integrity lead to effective and creative solutions and make vital contributions toward sustainable development (see Internet 2). With regard to sustainable development topics across the curriculum, we can mention the 2013/2014 results of a preliminary study of the syllabus for bachelor's and master's studies at the Faculty of Civil and Geodetic Engineering, University of Ljubljana. Analysis of the entire syllabus for bachelor's and master's programmes at the Faculty of Civil and Geodetic Engineering in Ljubljana showed that on average the topics of sustainable development, are better represented in the syllabus for the bachelor's programme compared to the master's programme. In the master's programme syllabus, one course stands out, which has a much greater proportion of topics on sustainability than other objects, but the topics on sustainable development in the master's program syllabus are represented more frequently compared to the syllabus the bachelor's programme (Terlević, 2014). In the 2011/2012 academic year, the University of Primorska introduced a new course called Sustainable Development in the master's programme (a program shared by different faculties), and it is also active in many other areas and projects (e.g., in 2014 the University of Primorska became a member of the UNESCO University Twinning and Networking Programme and a member of the UNESCO network Culture, Tourism, Development located at the Sorbonne).

\subsubsection{The importance of addressing sustainable spatial development issues in education early}

At the primary and secondary levels of education, the results of the major study Education on the Built Environment for the Sustainable Development of Slovenia (see Zupančič Strojan et al., 2009), which deals with the role of the concept of education in the built environment for sustainable development, suggests that curriculum content is relatively well prepared. "Even though the material is well prepared, implementing it is unrealistic due to the limited time of the course" (Zupančic Strojan et al., 2009: 160). Also, doubts are raised about the level of obligations about highlighted content and significant impacts of school compared with the rest of the environment, such as family, peers and so on, regarding the problems of sustainable development. Finally, the problem of the actual utilisation of the possibilities of cross-curricular links is also highlighted. The results of three surveys of elementary and secondary school teachers, in which a variety of teaching methods (brainstorming, fieldwork and role playing) compared teachers' perceptions of space between different activities, show that teachers "begin to look differently at different interests, behaviour and problems in space and are more seriously aware of the role of active citizenship in the process of spatial planning" (Fridl et al., 2009: 392). With the different treatment of existing content and the involvement of new content, teachers can expand pupils' and students' mental world. The findings of an international study - which took place as part of the international project Raising Awareness of Values of Space through the Process of Education and which sought to determine preferences and barriers perceived by both teachers and students in terms of content that refers to space and in terms of the use of teaching aids - showed that "there is statistically a significant difference in the education of spatial development between countries, that pupils are not sufficiently encouraged in the direction of learning about and understanding spatial content and, consequently, their knowledge of this content is at a considerably lower level" (Resnik Planinc, 2006: 20). Or, as Tatjana Resnik Planinc (2006: 20) concludes: in general, "topics relating to space and its values have not yet become an important part of peoples' everyday life." In any 
case, it is certainly necessary to encourage people toward this. One effective way of teaching and learning about sustainable development is learning in a natural environment with an area set up for this purpose (Vovk Korže, 2012), which creates a stimulating learning environment where pupils and students make decisions in real situations.

\subsubsection{Sustainable spatial development in higher education}

Elena Dimitrova (2014) presented ten years of experience in integrating themes about sustainable development and sustainable spatial planning in the academic program in urbanism at the Faculty of Architecture in Sofia. Although this project, which began in 2002, was a pilot project and was not prepared for radical changes in integrating sustainable spatial development in the curriculum and teaching in general, it contributed significant experience and strong arguments in support of sustainable spatial development in education, especially for individual professional areas. Other practical experience that was acquired confirmed the importance of gradual steps in the process of radical change at the institutional level. Dimitrova (2014) states that restructuring the curriculum in Europe in line with the Bologna process is an opportunity for closer regional cooperation in sustainable development and education for sustainable development. Neveen Hanza and Margare Horne (2007) described a three-year effort to teach sustainable spatial planning and three modules: design, visualisation and reducing energy consumption combined with low energy and passive construction. The authors' opinion is that in the future there is a need to gradually incorporate sustainable spatial planning into the existing courses and that for architecture it is crucial to follow the principle of sustainable development, to learn from past experience and to take advantage of today's technological advancements for establishing and maintaining current needs. Runming Yao and Koen Steemers (2009) presented an example of successful international cooperation between universities in education for a sustainable built environment. The Internet allows interaction between governments, universities, associations and business organisations between China and the European Union and strengthens mutual cooperation and information in sustainable development. The survey had a significant impact on promoting sustainable spatial development and it promotes sharing experiences with all stakeholders. Individual initiatives, projects, and programs that affected many factors (such as initiative, personality and leaders' abilities) seek to introduce a range of new teaching strategies to provide opportunities for teachers and other interested parties to consider how they can use these learning strategies in their teaching (Ferreira et al., 2007, 2009). Because the students' and teachers' conceptions of sustainable development are different, we analyse these two aspects separately.

\subsection{Students' conception of sustainable development}

Many studies address issues related to sustainable development and curriculum content and whether they are embedded in a learning environment, but only a small number of studies explore students' conception of sustainable development (Carew \& Mitchell, 2002; Kagawa, 2007) and teachers' conception of sustainable development (Cotton et al., 2007; Davis \& Gerard, 2013). Students most frequently understand sustainable development in the narrow sense (especially environmental aspects), which can slow down the overall development of environmental literacy (Kagawa, 2007). A study of students' conceptions of sustainable development by Adisa Azapagic et al. (2005) found that students believe that sustainable development is more important for future generations than for them personally and that students lack knowledge of the economic and social aspects of sustainable development, although they are relatively familiar with key environmental legislation, policies and standards. The authors also believe that there are major gaps in knowledge and in the connection between theory and practice. Similar findings were also reflected in a survey among students at the University of Oxford (see Summers et al., 2004), where a large proportion of students were found to be aware of the environmental aspects of sustainable development, a slightly smaller number were aware of the economic aspects and more than half of the students questioned were unfamiliar with the social dimension of sustainable development. John Stir (2006) and Fumiyo Kagawa (2007) believe that students are concerned about environmental issues and the environmental aspect of sustainable development, although their understanding of the social, cultural and economic aspects of sustainable development is superficial and inadequate, reflecting the large deficit of knowledge among students. A similar situation in sustainable development was also found in surveys by Ana Reid et al. (2009) and by Ana Carew and Cynthia Mitchell (2002); students viewed sustainable development differently, and primarily had a narrow understanding of sustainable development; that is, an environmental point of view. The authors suggest that, instead of focusing only on transferring information about sustainable development, teachers should encourage students to deal with the content of sustainable development in a way that enables them to develop their own knowledge about sustainable development and critical, contextual, ethical and sustainable creative thinking. A survey among students at a university in Turkey (see Eyuboglu et al., 2010) showed that most students are aware of the problems of sustainability; however, they are unfamiliar with the definitions, principles and objectives of sustainable development and also of its importance. This can cause serious problems in the dissemination of knowledge, information and thinking about the environment, environmental issues and sustainability among students. 


\subsection{Teachers' conception of sustainable development}

There is little research related to the conception of sustainable development among teachers in higher education (e.g., Cotton et al., 2007), but in recent years the number of such studies has been growing due to increasing awareness of the importance of this area (Fadeeva \& Mochizuki, 2010). Ana Reid and Peter Petocz (2006) and Reid et al. (2009) found, based on project work, that students and teachers view sustainable development differently and that teachers do not have adequate knowledge of teaching the topics in sustainable development. The authors have come to the conclusion, that the cooperative efforts of teachers in education for sustainable development are hindered for the following reasons: a lack of common understanding of this topic, lack of technical language to discuss environmental issues and a lack of enthusiasm for including these topics in the curriculum. Although some research has shown that experienced teachers believe that education for sustainable development is important (Huckle \& Sterling, 1996; Stir, 2006; Bjorneloo \& Nyberg, 2007), there is concern about the level of understanding of sustainability concepts in the teaching profession as a whole (Taylor et al., 2006), a wide range of understanding about sustainable development, a high level of critical debates about the concept of sustainable development (Cotton et al., 2007) and lack of confidence in teachers' abilities to teach about sustainable development (Stir, 2006). The results of a study on teachers' conceptions of sustainable development, which was conducted by Gerard Effeney and Julie Davis (2013), have shown that the majority of teachers believe that they are adequately trained to teach sustainable development. However, the study found no association between perceived and actual knowledge, which indicates that participants are either not concerned about their possible lack of knowledge about sustainable development or are unaware of their actual knowledge, which can consequently have a negative impact on their teaching skills. The indirect results of a study at Slovenian universities (willingness to participate in the study, mode of cooperation, etc.) demonstrated that "teachers and students at the university level are running out of energy to expand their perspectives and are overwhelmed with everyday problems. This partly mirrors the situation in (higher) education, which has its own external criterion (the economy and politics). All of this reflects the current mood regarding necessary changes in structural reforms of higher education" (Mlinar, 2010b: 15). The findings of other research on teachers' conceptions of sustainable development indicate a wide range of understanding concerning the topic of sustainable development inside educational institutions and a high level of critical discussion on the concept of sustainable development (Cotton et al., 2007).

\section{Reasons and measures to increase the involvement of sustainable development in education}

Some reasons that could explain the insufficient integration of sustainable development in higher education are lack of awareness of the importance of sustainable development $(\mathrm{Da}$ vis et al., 2003; Lozano, 2006), excessive curriculum (AbdulWahab et al., 2003; Chau, 2007), lack of support (Velazquez et al., 2005), perceptions of sustainable development as an irrelevant topic, uncertainty in efforts required to participate in and integrate sustainable development (Lozano, 2010), object scarcity of organisational structure (Velazquez et al., 2005; Lambrechts et al., 2009), lack of holistic thinking at the academic and administrative levels, lack of motivation and skills for specific changes, terminological vagueness of the concept, conservatism, fear of losing control and lack of financial support (Dimitrova, 2014). The following measures have been proposed to overcome the resistance of higher education institutions to integrate sustainable development: implementing the principles of sustainable development into academic activities and into everyday life and work, including more realistic teaching methods, including the content of sustainable development in all subject areas with an appropriate degree of cross-curricular links, gradually integrating sustainable development into the curriculum, taking advantage of the multiplier effects of sustainable development (Ferrer et al., 2010), preparing high-quality educational resources in sustainable development, enabling teachers to have access to examples of good practice and teaching materials for sustainable development, establishing new models of professional development and continued education and teacher training in sustainable development (Lourdel et al., 2005; Fadeeva, 2010), facilitating the integration of sustainable development through cooperation and promotion by the ministry and other departments, cooperating with other higher education institutions at the local and global levels, maintaining a vision and implementation plan for sustainable development, stating the reasons for change (Lozano, 2006), increasing or improving communication and providing feedback, holistically addressing issues of sustainable development, integrating social and economic issues, and motivating teachers and students to become actively involved in the process (Huisingh \& Mebratu, 2000; Rogers, 1995; Elton, 2003). Peter Glavič et al. (2009) state that it is necessary to incorporate the principles of sustainable development not only in the structure and organisation of universities, but also in educational programmes. "Sustainability can be achieved within the existing curriculum using three different methods. The University may incorporate sustainable development into existing curricula with adding sustainable content, offering optional subjects that deal with sustainable 
development and third, university can offer new degree programs that address sustainability content" [sic] (Glavič et al., 2009: 1145). Based on the discussion of how to integrate sustainable development into the higher education curriculum, Georg Müller-Christ et al. (2014) devised the following six methods of influencing the internal negotiation processes in order to increase the presence of sustainable development in higher education. According to them, these methods are also important for integrating sustainable spatial development into higher education, and so they suggest:

- An additional course in education for sustainable spatial development: because the integration of sustainable spatial development into all core subjects of a given academic program is a time-consuming process, it is more beneficial to offer an additional course in sustainable spatial development. The quickest way is to introduce it as an optional subject. The introduction of compulsory subjects requires a change in regulations, which may be a very time-consuming process without the widespread support of open-minded staff.

- Support of versatile open-minded people in educational institution: negotiations are simpler if the board, dean and teaching staff believe that education for sustainable spatial development is a key element of the mission of higher education institutions. The challenge is not only to convince colleagues that higher education institutions are responsible for promoting sustainable spatial development in the future, but also to promote preparedness to address the institutional compromises caused by education for sustainable spatial development at higher education institutions.

- The window of opportunity: the story of higher education institutions that have successfully incorporated education for sustainable development into the curriculum can be called a window of opportunity. Most of these higher education institutions had to undergo a thorough restructuring and also consequently modify their own profile as a higher education institution. The process depends on a solid foundation in appropriate environmental and social sciences. The window of opportunity for all higher education institutions is the Bologna Process, which provided a framework for common efforts to reform and modernise higher education systems. One of the important requirements is integration of the key competencies in the curriculum in the European Higher Education Area, and one of these competences is education for sustainable spatial development.

- External pressure: higher education institutions are exposed to the interests of various parties; for example, government, the labour market, funding agencies, and so on. In many cases, organisational changes in higher educational institutions are a response to pressure from external stakeholders. Experience shows that voicing opinions and making a plan from diverse stakeholders can help organisational actors (management) in creating pressure within their organisations for change towards a more sustainable higher education institution.

- Internal drivers: declarations of sustainable spatial development in higher education institutions can serve as key internal drivers, based on internal discussions and negotiations about integration of sustainable development in education, and this identifies the importance of education. Another key driver includes the internal mission and guidelines of sustainable spatial development, which can be derived from declarations and conclusions drawn from the wider discussion regarding higher education institutions.

- Incentives for professional development: teachers are a vital link in delivering and interpreting the content of the curriculum. Each incentive for introducing sustainable spatial development depends on the teaching staff, and their willingness and ability to provide opportunities for learning about the issues and challenges of sustainable development. For introducing sustainable spatial development, not only are new or additional teachers required, but also training opportunities for current teachers. The program should include a specific set of incentives so that teachers have the additional time required for developing a study subject and teaching competencies suitable for education for sustainable development. Nevertheless, it has been shown that support from administration and other staff may have a more important role than material incentives for teachers that participate in creating a modern curriculum incorporating a sustainable development paradigm.

\section{Conclusion}

Sustainable development in higher education is a major challenge, both now and in the future. Although there is a general definition of sustainable development ("[s]ustainable development is development that meets the needs of the present without compromising the ability of future generations to meet their own needs"; World Commission on Environment and Development, 1987: 43), sustainable development is difficult to define and consequently also to implement. The consequences are evident in all areas of human life. Although studies in sustainable development have increased, particularly in higher education, within the last two decades for many reasons, sustainable development in higher education is still in the early stages of development. Students, the future graduates who will make important decisions and thus contribute to a better future, most commonly understand sustainable 
development in the narrower sense; they are mostly familiar with the environmental aspect and their understanding of the economic, social and cultural point of view of sustainable development is inadequate and superficial. Also worrying is their point of view that sustainable development is more important for future generations and not for them personally, which may be a matter of concern because it suggests a lack of knowledge and skills that are needed in today's rapidly changing world. Education for sustainable development among students emphasises values and qualifies them for practical activities and democratic decision-making. This includes changing and influencing students' thinking, which is currently overspecialised and narrowly focused on more balanced, holistic, synergistic and interdisciplinary thinking. It is necessary to emphasise values and training for practical activities and rational (democratic) decision-making for better understanding a wide range of cross-disciplinary concepts and themes. In addition, the low level of spatial literacy and highlighting the need for introducing spatial education into the education system has been emphasised for a long time. Space is vital to human existence. There are many reasons for the lack of sustainable spatial development topics and themes in higher education, which must be solved gradually and with great persistence. Teachers believe that some of the reasons for the poor understanding of sustainable development topics and themes is a lack of professional language for discussing environmental issues, lack of enthusiasm for including these specific topics in the curriculum, curriculum redundancy with other themes and teachers' preoccupations with other daily activities. Therefore, it is necessary to implement measures to contribute to faster integration of sustainable development and a sustainable spatial development paradigm into the curriculum and education. Among the important measures are implementing more realistic teaching methods and problem-based tasks, content integration of sustainable development in all subject areas and cross-curricular connection, gradually introducing sustainable development into the curriculum, preparing high-quality educational resources, exchanging good practices between educational organisations, international cooperation, access to good-practice examples, opportunities for teacher training and implementing a sustainable development paradigm in everyday life.

Due to the importance of research on sustainable development in higher education, it is necessary to address a wide range of topics in this field. This study focuses on various notions of sustainable development in conjunction with sustainable spatial development in higher education, in particular by students that, as graduates, will hold jobs and make significant decisions in spatial management, with the future of the entire social environment depending on them. Of course, the quality of introducing and implementing sustainable spatial develop- ment in higher education requires a proactive approach from managers, employees, teachers, and students in higher education institutions and in society in general. Sustainable spatial development, aided by transdisciplinary activities, can become a leader in abolishing the old "unsustainable" paradigm and creating a new "sustainable" one. New, more flexible academic programs could be a base for developing effective measures to address the issues of sustainable spatial development and help in maintaining productivity in research, practice and implementing a sustainable spatial development paradigm. Sustainable development in general and thus also sustainable spatial development is not a discipline in itself, but is a context in which all disciplines can be taught. Eric Pappas (2012) states that it is entirely possible to integrate sustainable (spatial) development into all higher education programs, whereby each program could address one or more specific contexts. In the spatial planning process, there is also a need for balanced and meaningful consideration of all four aspects of sustainable development. Successful integration and implementation will require many additional research studies with focus on a more holistic view of sustainable development and research based on thinking outside traditional frameworks and thinking outside the box.

\author{
Maja Terlević \\ University of Primorska, Faculty of Education, Koper, Slovenia \\ E-mail: histra.maja@gmail.com \\ Andreja Istenič Starčič \\ University of Primorska, Faculty of Education, Koper, Slovenia \\ University of Ljubljana, Faculty of Civil and Geodetic Engineering, \\ Ljubljana, Slovenia \\ E-mail: andreja.istenic-starcic@fgg.uni-lj.si \\ Maruška Šubic Kovač \\ University of Ljubljana, Faculty of Civil and Geodetic Engineering, \\ Ljubljana, Slovenia \\ E-mail: maruska.subic-kovac@fgg.uni-lj.si
}

\section{Notes}

${ }^{[1]}$ The Ministry of Education and Sport was renamed the Ministry of Education, Science and Sport in 2012.

\section{References}

Abdul-Wahab, S. A., Abdulraheem, M. Y. \& Hutchinson, M. (2003) The need for inclusion of environmental education in undergraduate engineering curricula. International Journal of Sustainability in Higher Education, 4(2), pp. 126-137. DOI: 10.1108/14676370310467140

Azapagic, A., Perdan, S. \& Shallcross, D. (2005) How much do engineering students know about sustainable development? The findings of an international survey and possible implications for the engineering curriculum. European Journal of Engineering Education, 30(1), pp. 1-19. DOI: 10.1080/03043790512331313804 
Bizjak, I. (2012) Improving public participation in spatial planning with Web 2.0 tools. Urbani izziv, 23(1), pp. 112-124.

DOI: 10.5379/urbani-izziv-en-2012-23-01-004

Bizjak Končar, A., Snoj, M., Gložančev, A., Kern, B., Kostanjevec, P., Krvina, D., et al. (2013) Slovar novejšega besedja slovenskega jezika. Ljubljana, Založba ZRC, Research Centre of the Slovenian Academy of Sciences and Arts.

Bjorneloo, I. \& Nyberg, E. (eds.) (2007) Drivers and barriers for implementing learning for sustainable development in pre-school through upper secondary and teacher education. Technical paper, 4. UNESCO, Education Sector.

Bratina Jurkovič, N. (2014) Perception, experience and the use of public urban spaces by residents of urban neighbourhoods. Urbani izziv, 25(1), pp. 107-125. DOI: 10.5379/urbani-izziv-en-2014-25-01-003

Carew, A. L. \& Mitchell, C.A. (2002) Characterizing undergraduate engineering students' understanding of sustainability. European Journal of Engineering Education, 27(4), pp. 349-361. DOI: 10.1080/03043790210166657

Chau, K. W. (2007) Incorporation of sustainability concepts into a civil engineering curriculum. Journal of Professional Issues in Engineering Education and Practice, 133(3), pp. 188-191.

DOI: 10.1061/(ASCE)1052-3928(2007)133:3(188)

Cheal Ryu, H. \& Brody S. D. (2006) Examining the impacts of a graduate course on sustainable development using ecological footprint analysis. International Journal of Sustainability in Higher Education, 7(2), pp. 158175. DOI: $10.1108 / 14676370610655931$

Commission for Assessing the Quality of the University (2014) Zapisnik 16. redne seje Komisije za ocenjevanje kakovosti univerze, ki je potekala 12. junija 2014 na Univerzi v Mariboru s pričetkom ob 10.30 uri. Available at: http://www.um.si/kakovost/komisija-za-kakovost-univerz/Documents/ Zapisnik-16.seja(12.06.2014).pdf (accessed 1 Dec. 2014).

Cortese, A. D. (2003) The critical role of higher education in creating a sustainable development. Planning for Higher Education, 31(3), pp. 15-22.

Costanza, R. (1991) Ecological economics. The science and management of sustainability. New York, Columbia University Press.

Cotton, S. R. E., Warren, M. F., Maiboroda, O. \& Bailey, I. (2007) Sustainability development, higher education and pedagogy: A study of lecturers' beliefs and attitudes, Environmental Education Research, 13(5), pp. 579-597. DOI: 10.1080/13504620701659061

Davis, J. \& Gerard, E. (2013) Education for sustainability: A case study of pre-service primary teachers' knowledge and efficacy. Australian Journal of Teacher Education, 38(5), pp. 32-46. DOI: $10.1108 / 14676370310467177$

Davis, S. A., Edmister, J. H., Sullivan, K. \& West, C. K. (2003) Educating sustainable societies for the twenty-first century. International Journal of Sustainability in Higher Education, 4(2), pp. 169-179.

Department of Environment and Heritage (2005) Educating for a sustainable future. A national environmental education statement for Australian school [sic]. Carlton, Curriculum Corporatium.

Dimitrova, E. (2014) The "sustainable development" concept in urban planning education: Lessons learned on a Bulgarian path. Journal of Cleaner Production, 62, pp. 120-127. DOI: 10.1016/j.jclepro.2013.06.021

Economic Commission for Europe (2007) Environment for Europe. Learning from each other: Achievements, challenges and the way forward. United Nations.

Economic Commission for Europe (2008) Spatial planning. Key instrument for development and effective governance with special reference to countries in transition [sic]. United Nations.
Effeney, G., \& Davis, J. (2013) Education for sustainability: A case study of pre-service primary teachers' knowledge and efficacy. Australian Journal of Teacher Education, 38(5), pp. 32-46. DOI: 10.14221/ajte.2013v38n5.4.

Elton, L. (2003) Dissemination of innovations in higher education: A change theory approach. Tertiary Education and Management, 9(3), pp. 199-214. DOI: 10.1080/13583883.2003.9967104

Erkkila, T. (2014) Global university rankings, transnational policy discourse and higher education in Europe. European Journal of Education, 49(1), pp. 91-101. DOI: 10.1111/ejed.12063

European Commission (2014): Living well, within the limits of our planet. Available at: http://ec.europa.eu/environment/pubs/pdf/ factsheets/7eap/en.pdf (accessed 12 Dec. 2014).

Eyuboglu K. T., Uslu O. \& Oz M. D. (2010) Attitudes of university students towards economic and sustainable development in Istanbul. International Review of Business Research, 6(3), pp. 123-128.

Fadeeva, Z. \& Mochizuki, Y. (2010) Higher education for today and tomorrow: University appraisal for diversity, innovation and change towards sustainable development. Sustainability Science, 5(2), pp. 249256. DOI: $10.1007 / \mathrm{s} 11625-010-0106-0$

Ferreira, J., Ryan, L., Davis, J., Cavanagh, M. \& Thomas, J. (2009) Mainstreaming sustainability into pre-service teacher education in Australia. Canberra, Australian Research Institute in Education for Sustainability, Macquarie University for the Australian Government Department of the Environment, Water, Heritage and the Arts.

Ferreira, J., Ryan, L \& Tilbury, D. (2007) Planning for success: Factors influencing change in teacher education. Australian Journal of Environmental Education, 23(1), pp. 45-55.

Ferrer-Balas, D., Lozano, R., Huisingh, D., Buckland, H., Ysern, P. \& Zilahy, G. (2010) Going beyond the rhetoric: System-wide changes in universities for sustainable societies. Journal of Cleaner Production, 18(7), pp. 607-610. DOI: 10.1016/j.jclepro.2009.12.009

Fridl, J., Urbanc, M. \& Pipan, P. (2009) Pomen učiteljevega zaznavanja prostora v izobraževalnem procesu. Acta geographica Slovenica, 49(2), pp. 365-392.

Gabrijelčič, P. \& Fikfak, A. (2012) Igra ustvarjalnosti. Urbanistične, urbanistično-arhitekturne in planerske delavnice. Ljubljana, University of Ljubljana, Faculty of Architecture.

Giliberti, M. (2013) Rethinking the memorial in a Black Belt landscape: Planning, memory and identity of African Americans in Alabama. Urbani izziv, 24(1), pp. 144-159. DOI: 10.5379/urbani-izziv-en-2013-24-01-004

Glavič, P., Krajnc, D. \& Lukman, R. (2009) Fostering collaboration between universities regarding regional sustainability initiatives - The University of Maribor. Journal of Cleaner Production, 17, pp. 1143-1153. DOI: 10.1016/j.jclepro.2009.02.018

Gliha Komac, N., Jakop, N., Kern, B., Klemenčič, S., Krvina, D., Ledenik, N., et al. (2014) Slovar slovenskega knjižnega jezika: SSKJ 2. Ljubljana, Cankarjeva založba.

Hamza, N. \& Horne, M. (2007) Educating the designer: An operational model for visualizing low-energy architecture. Building and Environment, 42(11), pp. 3841-3847. DOI: 10.1016/j.buildenv.2006.11.003

Hiremath, R. B., Kattumuri, R., Kumar, B., Khatri, V. N. \& Patil, S. S. (2012) An integrated networking approach for a sustainable textile sector in Solapur, India. Urbani izziv, 23(2), pp. 114-121. DOI: 10.5379/urbani-izziv-en-2012-23-02-007.

Hoxha, V., Temeljotov Salaj, A. \& Dimitrovska Andrews, K. (2014) Cultural factors affecting urban planners' intentions to regulate public space 
in Prishtina, Kosovo. Urbani izziv, 25(2), pp. 76-89.

DOI: 10.5379/urbani-izziv-en-2014-25-02-001

Huckle, J. \& Sterling, S. (1996) Education for sustainability. London, Earthscan Publications.

Huisingh, G. \& Mebratu, D. (2000) Educating the educators as a strategy for enhancing education on cleaner production. Journal of Cleaner Production, 8(5), pp. 439-442. DOI: 10.1016/S0959-6526(00)00048-2

Internet 1: http://www.un.org/en/sustainablefuture/sustainability. shtml (accessed 15 Dec. 2014).

Internet 2: http://www.ef.uni-lj.si/trajnostni_razvoj (accessed 13 Dec. 2014).

Kagawa, F. (2007) Dissonance in students' perceptions of sustainable development and sustainability. International Journal of Sustainability in Higher Education, 8(3), pp. 317-338. DOI: 10.1108/14676370710817174.

Kauppi, N. \& Erkkila, T. (2011) The struggle over global higher education: Actors, institutions and practices. International Political Sociology, 5, pp. 314-326. DOI: 10.1111/j.1749-5687.2011.00136.x

Kokot Kranjc, A., Križan, J., Vovk Korže, A. \& Globovnik, N. (2011) Ecoremediation educational polygons in Slovenia as good examples of experiential learning of geography [sic]. Literacy Information and Computer Education Journal, 2(3), pp. 481-490.

Kolenc Kolnik, K. (2009) Geografsko izobraževanje je pomemben del izobraževanja za trajnostni razvoj. In: Kikec, T. (ed.) Zborovanje slovenskih geografov. Pomurje: trajnostni regionalni razvoj ob reki Muri: zbornik. pp. 450-457. Murska Sobota, Zveza geografov Slovenije in Društvo geografov Pomurja.

Koželj, J. (2012) Delavnice so najboljša oblika študija arhitekture in urbanizma. In: Fikfak, A., in Gabrijelčič, P. (ed.). Igra ustvarjalnosti. Urbanistične, urbanistično-arhitekturne in planerske delavnice, pp. 8-9. Ljubljana, Univerza v Ljubljani, Fakulteta za arhitekturo.

Kuhn, T. S. (1970) The structure of scientific revolutions. Chicago, University of Chicago Press.

Kušar, S. (2008) Aktualizacija učnih vsebin z vidika vrednot prostora in participacije javnosti v procesu prostorskega planiranja. Dela, (29), pp. 37-48.

Kušar, S. (2012) Selected spatial effects of the global financial and economic crisis in Ljubljana, Slovenia. Urbani izziv, 23(2), pp. 112-120. DOI: 10.5379/urbani-izziv-en-2012-23-02-004

Lambrechts, W., Vanhoren, I. \& Van den Haute, H. (2009) Sustainable higher education. Appeal for responsible education, research and operations. Leuven, Lannoo Campus.

Lourdel, N., Gondran, N., Laforest \& V. Brodhag, C. (2005) Introduction of sustainable development in engineers' curricula. Problematic and evaluation methods. International Journal of Sustainability in Higher Education, 6(3), pp. 254-264. DOI: 10.1108/14676370510607223

Lovelock, J. (2007) The revenge of Gaia. London, Penguin Group.

Lozano, R. (2006) Incorporation and institutionalization of SD into universities: Breaking through barriers to change. Journal of Cleaner Production, 14(9-11), pp. 787-796. DOI: 10.1016/j.jclepro.2005.12.010

Lozano, R. (2010) Diffusion of sustainable development in universities' curricula: An empirical example from Cardiff University. Journal of Cleaner Production, 18(7), pp. 637-644.

DOI:10.1016/j.jclepro.2007.01.002

Lozano, R. (2011) The state of sustainability reporting in universities. International Journal of Sustainability in Higher Education, 12(1), pp. 67-78. DOI:10.1016/j.jclepro.2007.01.002

Lozano, R. (2012) Towards a more effective and efficient SD incorporation into universities. In: Higher education in the world 4 - Higher education's commitment to sustainability: From understanding to action. New York, Global University Network for Innovation and Palgrave Macmillan.

Lukman, R. (2009) Trajnostni razvoj v visokošolskem izobraževanju: Učinkovita in okoljsko odgovorna univerza. Doctoral thesis. Maribor, University of Maribor, Faculty of Chemistry and Chemical Technology.

Ministry of Education and Sport (2007a) Poročilo o udeležbi na konferenci okolje za za Evropo. Belgrade. Available at: http://www.mizs.gov.si/ fileadmin/mizs.gov.si/pageuploads/podrocje/mednarodno/solstvo/doc/ Beograd_okolje_oktober07.doc (accessed 10 Nov. 2014).

Ministry of Education and Sport (2007b) Smernice vzgoje in izobraževanja za trajnostni razvoj od predšolske vzgoje do douniverzitetnega izobraževanja. Ljubljana.

Mlinar, A. (2010a) Paradigma trajnosti in izobraževanje. Raziskava na slovenskih univerzah s posebnim ozirom na Univerzo na Primorskem. Annales, 20(1), pp. 119-130.

Mlinar, A. (2010b) Etika v izobraževanju za trajnostni razvoj. Zaključno poročilo o rezultatih opravljenega raziskovalnega dela na projektu $v$ okviru ciljnega raziskovalnega programa (CRP) "Konkurenčnost Slovenije 20062013". Koper, University of Primorska, Science and Research Centre.

Mulder, K. (2010) Don't preach. Practice! Value laden statements in academic sustainability education. International Journal of Sustainability in Higher Education, 11(1), pp. 74-85. DOI: 10.1108/14676371011010066

Müller-Christ, G., Rietje van Dam-Mieras, S., Adomßent, M., Fischer, D. \& Rieckmann, M. (2013) The role of campus, curriculum, and community in higher education for sustainable development - A conference report. Journal of Cleaner Production, 62, pp. 134-137. DOI: 10.1016/j.jclepro.2013.02.029

Nevin, E. (2008) Education and sustainable development. Education and sustainable development. Policy and Practice: A Development Education Review, 6, pp. 49-62.

Nonaka, I. \& Takeuchi, H. (2001) Organizational knowledge creation. In: Henry, J. (ed.) Creative management, second edition, pp. 64-83. London, Sage Publications Ltd.

Orr, D.W. (1992) Ecological literacy: Education and the transition to a postmodern world. Albany, NY, State University of New York Press.

Pappas, E. (2012) A new systems approach to sustainability: university responsibility for teaching sustainability in contexts. Journal of Sustain ability Education, 3. Available at: http://www.jsedimensions.org/wordpress/content/a-new-systems-approach-to-sustainability-university-responsibility-for-teaching-sustainability-in-contexts_2012_03/ (accessed 13 Nov. 2013).

Rebolj, D., Lorber, L., Glavič, P., Kovačič Lukman, R., Mulej, M., Vovk Korže, A., et al. (2012) Strategija trajnostne in družbeno odgovorne univerze TDOUM (2012). Trajnostna in družbeno odgovorna Univerza $v$ Mariboru. Maribor, University of Maribor.

Reid, A. \& Petocz, P. (2006) University lecturers' understanding of sustainability. Higher Education, 51(1), pp. 105-123. DOI: 10.1007/s10734-004-6379-4

Reid, A., Petocz, P. \& Taylor, P. (2009) Business students' conceptions of sustainability. Sustainability, 1(3), pp. 662-673. DOI: 10.3390/su1030662

Resnik Planinc, T. (2006) Vrednote prostora kot integralni del izobraževanja. Geodetski vestnik, 78(2), pp. 9-24.

Richter, T. \& Schumacher, K. P. (2011) Who really cares about higher education for sustainable development? Journal of Social Sciences, 7(1), pp. 24-32.

Robinson, J. (2008) Being undisciplined: Transgressions and intersections in academia and beyond. Futures, 40(1), pp. 70-86. DOI: 10.1016/j.futures.2007.06.007 
Rogers, E.M. (1995) Diffusion of innovations. New York, Free Press.

Sarewitz, D., Clapp, R., Crumbley C., Kriebel, D. \& Tickner, J. (2012) The sustainability solution agenda. New Solutions, 22(2), pp. 139-151. DOI: 10.2190/NS.22.2.C

Simoneti, M. (2006) Education for cooperation: Spatial planning needs to be taught! Urbani izziv, 17(12), pp. 119-125.

Sterling, S. \& Scott, W. (2008) Editorial. Environmental Education Research, 14(4), pp. 383-385. DOI: 10.1080/13504620802343862

Stir, J. (2006) Restructuring teacher education for sustainability: Student involvement through a strength model. Journal of Cleaner Production, 14(9-11), pp. 830-836. DOI: 10.1016/j.jclepro.2005.11.05

Summers, M., Corney, G. \& Ghilds, A. (2004) Student teachers conceptions of sustainable development: The starting-points of geographers and scientists. Educational Research, 46(2), 163-82.

DOI: $10.1080 / 0013188042000222449$

Taylor, N., Kennedy, J., Jenkins, K. \& Callingham, R. (2006) The impact of an education for sustainability unit on the knowledge and attitudes of pre-service primary teachers at an Australian university. Geographical Education, 19, pp. 46-59.

Terlević, M. (2014) Raziskava: pojmovanje trajnostnega razvoja študentov $v$ visokošolskem izobraževanju. Typescript (received 13 Nov. 2014).

U-Multirank (2014) Universities compared. Your way. Available at: http:// www.u-multirank.eu (accessed 13 Dec. 2014).

United Nation Conference on Education and Development (1992) The global partnership for environment and development: $A$ guide to Agenda 21 / United Nations conference on education and development. Geneva.

United Nations (2014) The road to dignity by 2030: Ending poverty, transforming all lives and protecting the planet. Available at: http://sustainabledevelopment.un.org/content/documents/5527SR_advance $\% 20$ unedited_final.pdf (accessed 13 Dec. 2014).

University of Maribor (2013) Strategija razvoja Univerze v Mariboru (2013-2020). Available at: http://www.um.si/univerza/predstavitev/ Strani/Poslanstvo-in-vizija.aspx (accessed 12 Dec. 2014).

Van de Ven, A.H., Polley, D.E., Garud, R. \& Venkataraman, S. (1999) The innovation journey. Oxford, Oxford University Press.

Velazquez, L., Munguia, N. \& Sanchez, M. (2005) Deterring sustainability in higher education institutions: An appraisal of the factors which influence sustainability in higher education institutions. International Journal of Sustainability in Higher Education, 6(4), pp. 383-391. DOI: $10.1108 / 14676370510623865$

Verovšek, Š. \& Juvančič, M. (2009) Identifying spatial values in the opinions of teenagers. Urbani izziv, 20(1), pp. 164-174.

DOI: 10.5379/urbani-izziv-en-2009-20-01-004

Verovšek, Š., Juvančič, M. \& Zupančič, T. (2013) Using visual language to represent interdisciplinary content in urban development: Selected findings. Urbani izziv, (24)2, pp. 144-155.

DOI: 10.5379/urbani-izziv-en-2013-24-02-006.

Vovk Korže, A. (2012) The ecoremediation educational polygon: A "classroom in nature". Geography, 97(2), pp. 95-99.

Waas, T., Verbruggen A. \& Wright, T. (2010) University research for sustainable development: Definition and characteristics explored. Journal of Cleaner Production, 18(7), pp. 629-636. DOI: 10.1016/j. jclepro.2009.09.017

Wals, A. (ed.) (2008) From cosmetic reform to meaningful integration: Implementing education for sustainable development in higher education institutes - The state of affairs in six European countries. Amsterdam, $\mathrm{DHO}$
Wemmenhove, R. \& de Groot, W.T. (2001) Principles for university curriculum greening. An empirical case study from Tanzania. International Journal of Sustainability in Higher Education, 2(3), pp. 267-283. DOI: 10.1108/14676370110388354

World Commission on Environment and Development (1987) Our common future. Oxford, Oxford University Press.

Wright, T. (2006) Giving teeth to environmental policy. Journal of Cleaner Production, 12(9-11), pp. 761-168.

Yao, R. \& Steemers, K. (2009) Overview of an innovative EU-China collaboration in education and research in sustainable built environment. Renewable Energy, 34 (9), pp. 2080-2087.

DOI: 10.1016/j.renene.2009.02.005

Yau, Y., Chiu, S. M. \& Lau, W. K. (2014) Economising subsidies for green housing features: A stated preference approach. Urbani izziv, 25(2), pp. 107-118. DOI: 10.5379/urbani-izziv-en-2014-25-02-003

Zakon o prostorskem načrtovanju. Uradni list Republike Slovenije, no. 33/2007. Ljubljana.

Zavodnik Lamovšek, A. \& Foški, M. (2012) Interdisciplinarni pristop k izvedbi urbaništično planerskih delavnic. In: Fikfak, A. \& Gabrijelčič, P. (ed.) Igra ustvarjalnosti. Urbanistične, urbanistično-arhitekturne in planerske delavnice, pp. 62-78. Ljubljana, University of Ljubljana, Faculty of Architecture.

Zhang, J., Kotze, N. \& Yu, M. (2012) Living in a changing Chinese urban landscape: The Dalian case study. Urbani izziv, 23(2), pp. 93-112. DOI: 10.5379/urbani-izziv-en-2012-23-02-002

Zupančič Strojan, T., Novljan, T., Juvančič, M., Verovšek, Š., Šubic Kovač M., Istenič Starčič, A. \& Svetina, M. (2009) Izobraževanje o grajenem okolju za trajnostni razvoj Slovenije: končno poročilo. Research report. Ljubljana, University of Ljubljana, Faculty of Architecture, Faculty of Civil and Geodetic Engineering, Faculty of Arts. 